\title{
DIMETILSULFOKSID SEBAGAI ENHANCER TRANSPOR TRANSDERMAL TEOFILIN SEDIAAN GEL
}

\section{DIMETHYLSULFOXIDE AS AN ENHANCER OF TRANSDERMAL TRANSPORT OF THEOPHYLLINE IN GEL DOSAGE FORMS}

\author{
Resty Annisa Damayanti, Tedjo Yuwono \\ Fakultas Farmasi Universitas Ahmad Dahlan \\ Jl. Dr. Soepomo, Yogyakarta, Telp. (0274) 379418 \\ Email : tedjo yuwono@yahoo.com
}

\begin{abstract}
Abstrak
Dimetilsulfoksid (DMSO), di Jerman sudah dipelajari secara intensif sejak abad ke-19. Bahan ini telah digunakan sebagai obat, sebagai pelarut juga sebagai enhancer absorpsi obat, baik obat sintetik maupun herbal. Pada studi ini diteliti pengaruh DMSO sebagai enhancer absorpsi transdermal teofilin, yang sediaannya banyak digunakan untuk antiselulit Percobaan absrpsi secara transdermal ini dilakukan secara in vitro dari sediaan gel, menggunakan kulit tikus jantan galur Wistar dengan alat difusi tipe vertikal. Ada empat formula gel masing-masing mengandung $7 \%$ teofilin dan mengandung DMSO dengan konsentrasi yang bervariasi antara $0 \%-7 \%$. Hasil percobaan menunjukkan bahwa DMSO memiliki potensi enhancer yang besar terhadap permeasi teofilin menembus membran kulit tikus. Makin tinggi konsentrasi DMSO makin tinggi pula nilai fluks. Formula yang mengandung $7 \%$ DMSO

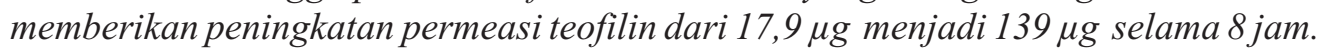

Kata Kunci : DMSO, enhancer, teofilin 


\section{Abstract}

Dimethylsulfoxide (DMSO) has been intensively studied the $19^{\text {th }}$ century. This substance is used as a medicine and solve. It can also be used as an absorption enhancer of various drugs, either synthetical or herbal medicines. This study conducted with DMSO as transdermal absorption enhancer of theophylline, which often used as an anti-cellulite dosage forms. The experiments studied in vitro transdermal absorption of theophylline in gel dosage forms, containing $7 \%$ theophylline dan various concentration of DMSO i.e. $0 \%, 3 \%, 5 \%$ and $7 \%$ DMSO respectively. These studies used skin membrane of Wistar strain male rats in a vertical type diffusion Cell. The results indicated that DMSO was very potential as a permeation enhancer theophylline, the formula containing $7 \%$ DMSO increased the theophylline transport from $17,9 \mu \mathrm{g}$ to $139,1 \mu \mathrm{g}$.

Key word : $\quad$ DMSO, enhancer, theophylline

\section{PENDAHULUAN}

Pada abad ke-19 dimetilsulfoksid (DMSO) sudah mulai teliti secara ekstensif di industri kimia di Jerman (Caprotti and Caprotti, 2012). Bahan ini telah digunakan sebagai obat, pelarut dan dapat pula sebagai enhancer dalam proses absorpsi obat, baik secara oral maupun transdermal. Sebagai bahan obat, DMSO memiliki efek antiinflamasi, analgetik dan sebagai antioksidan. DMSO juga dapat digunakan untuk amyloidosis, suatu kondisi dimana beberapa macam protein terdeposit secara abnormal di jaringan tertentu. Penggunaannya dapat melalui oral, topikal maupun intravena (Baumamm, 2002).

Jacob dan Hershler (2011), telah memaparkan kegunaan DMSO dengan berbagai tujuan, antara lain sangat potensial dalam meningkatkan efek obat anti-kanker dan membantu penetrasi / transpor obat lewat membran untuk beberapa obat, misalnya: beberapa $\alpha$-blockers, papaverin hidroklorida dan efedrin hidroklorida. DMSO dapat pula digunakan sebagai diuretik, vasodilatasi, muscle relaxation, pengaruhnya terhadap kadar kolesterol darah, penghalang platelet aggregation dan proteksi terhadap ischemic injury (Anonim, 2013 ${ }^{\mathrm{a}}$; Anonim 2013 ${ }^{\mathrm{b}}$ ).

Teofilin, aminofilin dan kofein, masing-masing adalah turunan xantin yang dapat menstimulasi terjadinya lipolisis (Djajadisastra et al., 2008; Kravitz and Achenbach, 2011), sehingga banyak digunakan sebagai obat antiselulit.

Selulit merupakan penyakit metabolisme lemak, terjadi pada jaringan subkutan, menyebabkan tidak meratanya permukaan tubuh, terjadi penonjolan pada jaringan adipose. Kelainan metabolisme ini lebih sering terjadi pada wanita daripada pria, biasanya muncul di perut, paha dan pantat. Bahan obat 
yang sering digunakan sebagai antiselulit adalah golongan xantin (kofein, teofilin atau aminofilin). Adapun mekanisme terjadinya lipolisis oleh golongan xantin melalui mekanisme inhibisi fosfodiesterase, sehingga bahan tersebut dapat menginduksi terjadinya lipolisis (Baumann, 2002). Sediaan antiselulit yang banyak digunakan adalah topical transdermal, karena sediaan ini lebih aman dan lebih efektif. Kendala pada pemberian obat secara topikal adalah lapisan kulit terluar, stratum corneum yang merupakan barrier utama penetrasi obat masuk melewati kulit.

Secara garis besar, kulit terdiri dari tiga lapis, yaitu epidermis, dermis dan hypodermis. Epidermis tersusun dari beberapa lapisan. Lapisan kulit terluar adalah stratum corneum, di bawahnya melputi stratum lucidum, stratum granulosum, stratum spinosum dan stratum germinativum (Donnelly et al, 2012). Stratum corneum merupakan lapisan barrier utama, tersusun oleh 25 sampai 30 lapis sel yang sudah mati, yang terdiri dari lipid (fosfolipid, glikolipid, kolesterol sulfat, dan protein) (Kumar et al., 2011). Tebal lapisan stratum corneum ini pada manusia antara 10 - 50 ìm dan pada hairless mouse hampir sama yatu antara 10 - 40 ìm (Higuchi et al., 1985). Hasil percobaan Kolb et al., cit. Jacob dan Herschler 1983, dalam percobaannya membandingkan absorpsi transdermal antara tikus dan manusia, dengan menggunakan label DMSO (S35) menunjukkan bahwa DMSO yang dilabel, yang dicobakan pada kulit manusia, 5 menit setelah pemberian sudah muncul di darah, sedangkan pada tikus perlu waktu 10 menit.

DMSO dapat merubah konformasi keratin stratum corneum dari $\alpha$-helical conformation menjadi $\beta$-sheet conformation (Trommer and Neubert, 2006). DMSO dapat meningkatkan fluks obat melalui interaksinya dengan lipid pada stratum corneum, merubah struktur protein, yang menyebabkan terjadinya perubahan nilai koefisien partisinya (Shembale et al., 2010). Terjadinya perubahan-perubahan ini yang menjadi dasar DMSO dapat berperan sebagai enhancer penetrasi membran kulit melalui proses difusi.

Proses difusi merupakan proses mass-transfer. Proses transfer massa yang terjadi secara alami mengikuti Hukum Fick pertama (Martin et al., 1993) yaitu:

$\mathrm{J}=\frac{\mathrm{dM}}{\mathrm{S} \cdot \mathrm{dt}}$

dengan, $\mathrm{J}$ adalah fluks yaitu jumlah massa zat (M) yang berdifusi melalui satuan unit luas bidang difusi (A) per satuan waktu $(\mathrm{t})$, dan besarnya fluks ini sebanding dengan konsentrasi gradien, dengan persamaan

$\mathrm{J}=-\mathrm{D} \frac{\mathrm{dC}}{\mathrm{Dx}}$

dengan $\mathrm{D}=$ koefisien difusi, $\mathrm{C}=$ konsentrasi dan $\mathrm{x}=$ jarak gerakan tegak lurus dari permukaan batas tersebut. Tanda negatif pada persamaan (2) menunjukkan difusi berjalan dengan arah berlawanan dengan naiknya konsentrasi, berarti difusi berjalan 
seiring dengan menurunnya konsentrasi (Martin et al., 1993)

Jika suatu proses difusi melalui membran dengan luas $\mathrm{A}$ dan tebal $\mathrm{h}$, serta konsentrasi di kedua permukaan membran berturut-turut adalah $\mathrm{C}_{1}$ dan $\mathrm{C}_{2}$, dengan menggabungkan persamaan (1) dan (2) akan didapat :

$\mathrm{J}=\frac{\mathrm{dM}}{\mathrm{Adt}}=\mathrm{D} \frac{\mathrm{C}_{1}-\mathrm{C}_{2}}{\mathrm{~h}}$

Konsentrasi $\mathrm{C}_{\mathbf{1}}$ dan $\mathrm{C}_{\mathbf{2}}$ tidak diketahui, yang diketahui adalah konsentrasi kedua kompartemen yang dipisahkan oleh membran, misalkan konsentrasi masing-masing kompartemen adalah $\mathrm{Cd}$ dan $\mathrm{Cr}$, maka $\mathrm{C}_{1}$ dan $\mathrm{C}_{2}$ berturut-turut dapat diganti dengan mengalikan koefisien partisi $\mathrm{K}$, atau

$\mathrm{K}=\frac{\mathrm{C}_{1}}{\mathrm{Cd}}=\frac{\mathrm{C}_{2}}{\mathrm{Cr}}$

Jika kondisi dalam keadaan sink $\left(\mathrm{C}_{2}<<<\mathrm{C}_{1}\right)$, maka persamaan (3) dapat ditulis menjadi

$\frac{\mathrm{dM}}{\mathrm{Adt}}=\frac{\mathrm{D} \mathrm{K} \mathrm{Cd}}{\mathrm{h}}=\mathrm{P} \mathrm{Cd}$

dengan $\mathrm{P}=$ permeabilitas $=\mathrm{DK} / \mathrm{h}$. Jika persamaan (5) diintegrasikan akan diperoleh

$\frac{M}{A}=\frac{D K C d}{h}\left(t-t_{L}\right)$

Hubungan antara M/A vs t akan diperoleh persamaan linear dengan slope $=$ fluks $=(\mathrm{DKCd}) / \mathrm{h}$. Jika slope kurva tersebut diekstrapolasikan ke sumbu $\mathrm{t}$ (waktu) akan memotong sumbu tersebut di titik $\mathrm{t}_{\mathrm{L}}$ atau lag-time, dan lag-time ini diasumsikan sebagai waktu yang diperlukan suatu penetran untuk menyamakan konsentrasinya dalam membran, dengan persamaan (Martin et al., 1993):

$\mathrm{t}_{\mathrm{L}}=\frac{\mathrm{h}^{2}}{6 \mathrm{D}}$

Tujuan penelitian ini adalah untuk mengetahui kemampuan DMSO dalam meningkatkan penetrasi teofilin melalui membran kulit tikus dari sediaan gel dengan menggunakan sel difusi Franz yang telah dimodifikasi.

\section{METODE PENELITIAN}

Alat

Alat yang digunakan pada penelitian ini adalah sel difusi Franz yang dimodifikasi, yang dibuat oleh Bengkel Fisika FMIPA UGM Yogyakarta, magnetic stirrer (Thermoline dilengkapi magnetic bar), alat bedah, Spektrofotometer UV-Vis (Shimadzu 1700), pH-meter (Tipe pH3110 set 2, Germany), alat-alat untuk preparasi pembuatan sediaan gel.

\section{Bahan}

Teofilin extra pure (E Merck), dan dimetilsulfoksid, Carbopol 940, trietanolamin, metil paraben, propil paraben, masing-masing dengan derajad farmasetis. 
Bahan-bahan yang digunakan untuk uji transdermal selain yang tersebut di atas, digunakan juga dinatrium fosfat p.a., kalium diforfat p.a., kalium klorida p.a., natrium klorida p.a., $\mathrm{NaOH}$ p.a. $\mathrm{HCl}$ p.a. masing-masing dari E. Merck, serta tikus galur Wistar jantan umur kira-kira 2 bulan

\section{Jalannya Peneltian}

\section{Tahap Persiapan}

Dibuat larutan $\mathrm{NaOH} 0,1 \mathrm{M}$; $\mathrm{HCl}$ 0,1 M serta larutan PBS (Phosphate Buffer Saline) 0,1 M dengan $\mathrm{pH}$ 7,4, Pembuatan larutan stok teofilin dalam PBS 0,1 M dengan $\mathrm{pH} 7,4$.

\section{Pembuatan Kurva Baku Teofilin}

Pembuatan kurva baku dilakukan dengan diawali penentuan panjang gelombang serapan maksimum, pembuatan seri larutan teofilin dalam pelarut PBS 0,1 pH 7,4 dari konsentrasi 0,02 sampai $16,0 \mu \mathrm{g} / \mathrm{mL}$ penentuan LOD dan LOQ, kemudian diambil kadar yang absorbansinya di atas LOQ, lalu dibuat persamaan regresi linear hubungan antara konsentrasi teofilin dan absorbansinya, yang dinyatakan sebagai persamaan kurva baku untuk menghitung kadar sampel.

\section{Formulasi Pembuatan Gel Teofilin}

Formula sediaan gel teofilin dibuat dengan variasi konsentrasi DMSO, dengan komposisi seperti dipaparkan pada tabel I

Teofilin dilarutkan dalam larutan DMSO dalam air yang tersedia, kemudian metil paraben dan propil paraben dilarutkan pula dalam campuran tersebut. Carbopol 940 setelah dikembangkan lalu dicampur dengan larutan di atas dalam mortir, diaduk sampai homogen, lalu trietanolamin diteteskan, selanjutnya campuran diaduk sampai terbentuk gel yang jernih.

\section{Penyiapan Kulit Tikus}

Tikus dikorbankan, diambil kulit punggungnya digunakan sebagai model membran. Lemak pada lapisan kulitnya dihilangkan, dipotong bentuk bulat

Tabel I. Formulasi gel teofilin dengan berbagai konsentrasi DMSO

\begin{tabular}{|l|c|c|c|c|}
\hline \multirow{2}{*}{ Bahan } & \multicolumn{4}{|c|}{ Kadar DMSO } \\
\cline { 2 - 5 } & $\mathbf{F 1}$ & $\mathbf{F 2}$ & $\mathbf{F 3}$ & $\mathbf{F 4}$ \\
& $\mathbf{( 0 \% )}$ & $\mathbf{( 3 ~ \% )}$ & $\mathbf{( 5 ~ \% )}$ & $\mathbf{( 7 ~ \% )}$ \\
\hline Teofilin & 7 & 7 & 7 & 7 \\
Carbopol & 2 & 2 & 2 & 2 \\
Trietanolamin & 0,5 & 0,5 & 0,5 & 0,5 \\
DMSO & 0 & 3 & 5 & 7 \\
Metil paraben & 0,2 & 0,2 & 0,2 & 0,2 \\
Propil paraben & 0,1 & 0,1 & 0,1 & 0,1 \\
Aquades & ad 100 & ad 100 & ad 100 & ad 100 \\
\hline
\end{tabular}


dengan ukuran diameter sesuai dengan ukuran di sel difusi. Kulit yang sudah dipotong dan dibentuk, lalu direndam dalam larutan PBS 0,1 $\mathrm{M}$ dan $\mathrm{pH} 7,4$ untuk proses hidrasi selama 1 jam

\section{Uji Difusi In Vitro Gel Teofilin}

Uji in vitro dilakukan dengan alat vertical diffusion cell. Potongan kulit dipasang di antara kompartemen donor dan reseptor. Stratum corneum-nya menghadap ke kompartemen donor. Kompartemen reseptor diisi $20,0 \mathrm{ml}$ larutan PBS 0,1 pH 7,4 dan komponen donor diisi 3 gram gel teofilin. Pengadukan dilakukan di kompartemen reseptor dengan kecepatan $50 \mathrm{rpm}$ dan suhu dipertahankan pada $35^{\circ} \mathrm{C}$. Sampel larutan di kompartemen reseptor diambil setelah 0,5 jam, 1 jam dan berikutnya sampel diambil tiap jam sampai 8 jam. Volume sampel yang diambil $2 \mathrm{ml}$ tiap kali pengambilan dan volume yang diambil diganti larutan PBS dengan volume yang sama. Sampel yang diambil kemudian ditentukan konsentrasi teofilinnya. Setiap uji dilakukan replikasi 5 kali. Dari hasil percobaan ini dapat ditentukan besarnya fluks, permeabilitas dan efisiensi transpor teofilin.

\section{Analisis Hasil}

Dengan menggunakan kurva baku, data yang diperoleh masingmasing sampel ditentukan konsentrasinya. Jumlah kumulatif teofilin yang ditransport diplotkan sebagai fungsi waktu, akan diketahui masa tunak (steady state). Setelah diketahui masa tunaknya, ditentukan harga fluks dengan persamaan (6), lag time, koefisien difusi dengan persamaan (7) dan efisiensi. Data yang diperoleh diuji statistik dengan taraf kepercayaan $95 \%$.

\section{HASIL DAN PEMBAHASAN}

Hasil scanning pembuatan kurva baku diperoleh serapan panjang gelombang maksimum teoflin pada $272,2 \mathrm{~nm}$, harga LOD sebesar 1,086 $\mu \mathrm{g} / \mathrm{mL}$ dan harga LOQ sebesar 3,530 $\mu \mathrm{g}$ $/ \mathrm{mL}$. Data yang diperoleh, yang harganya kurang dari harga LOC dan LOQ tersebut diabaikan.

Hasil plot antara serapan/ absorbansi sebagai fungsi konsentrasi diperoleh persamaan kurva baku $\mathrm{Y}=$ $0,050 \mathrm{X}+0,038$ dengan $\mathrm{r}=0,9950>$ 0,4973 (r-tabel), sehingga ada hubungan signifikan antara konsentrasi dan absorbansi.

Selanjutnya gel masing-masing formula diuji transfer in vitro dengan menggunakan sel difusi, dilakukan selama 8 jam dan dilakukan 5 kali replikasi untuk tiap formula. Hasil ini kemudian ditentukan jumlah transfer teofilin sebagai fungsi waktu, dihitung pula nilai fluks, lag time dan koefisien difusi transpor teofilin melalui membran kulit tikus.

Hasil uji transfer teofilin dapat ditunjukkan pada gambar 1 . 


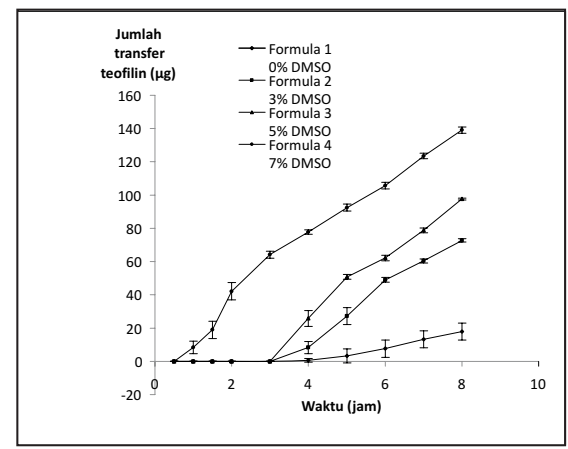

Gambar 1. Profil transpor teofilin melalui membran kulit tikus dari sediaan gel yang mengandung DMSO dengan berbagai konsentrasi

Dari gambar 1 terbukti bahwa penambahan DMSO dapat meningkatkan transfer teofilin, dan makin tinggi konsentrasi DMSO makin besar pula kemampuan DMSO sebagai enhancer. Dalam percobaan tersebut digunakan konsentrasi tertinggi DMSO 7\%. Pada konsentrasi ini ternyata belum maksimal sebagai enhanser, dari hasil percobaan pada kadar $7 \%$ DMSO kurva tranfer teofilin belum sampai menunjukkan nilai puncak.

Dengan demikian pada konsentrasi yang tebih tinggi dapat diperkirakan dapat lebih meningkatkan transfer teofilin. Karena $60 \%$ merupakan batas kritik DMSO dapat menimbulkan iritasi pada kulit (Trommer and Neubert, 2006), maka ada harapan besar sediaan gel teofilin selain dapat sebagai antiselulit yang efektif menghasilkan efek di perifir, sangat mungkin dapat digunakan sebagai antiasma dengan mengatur menaikkan konsentrasi DMSO agar kadar teofilin dalam plasma dapat mencapai terapeutic plasma level pada pengobatan asma. Pemberian teofilin rute transdermal selain lebih aman juga lebih nyaman digunakan dibanding pemberian melalui rute yang lain.

Tabel II. Nilai fluks, lag time dan koefisien difusi transfer teofilin dar sediaan gel yang mengandung DMSO dengan berbagai konsentrasi

\begin{tabular}{|c|c|c|c|}
\hline Sediaan & $\begin{array}{c}\text { Fluks } \\
\left(\mu \mathrm{g} \mathrm{cm}^{-2} \mathrm{jam}^{-1}\right)\end{array}$ & $\begin{array}{l}\text { Lag time } \\
\text { (jam) }\end{array}$ & $\begin{array}{c}\text { D } \\
\left(\mathrm{cm}^{2} \operatorname{det}^{-1}\right) \\
\times \mathbf{x}^{-3}\end{array}$ \\
\hline $\begin{array}{l}\text { Formula } 1 \\
\text { Formula } 2 \\
\text { Formula } 3 \\
\text { Formula } 4\end{array}$ & $\begin{array}{l}4,3 \pm 1,0 \\
26,0 \pm 1,1 \\
27,2 \pm 1,5 \\
44,5 \pm 1,9\end{array}$ & $\begin{array}{r}4,0 \pm 0,7 \\
4,0 \pm 0,6 \\
3,2 \pm 0,6 \\
1,1 \pm 0,4\end{array}$ & $\begin{array}{r}2,3 \pm 0,2 \\
2,7 \pm 0,6 \\
3,5 \pm 0,7 \\
12,0 \pm 8,6\end{array}$ \\
\hline
\end{tabular}


Hasil perhitungan nilai fluks, lag time dan koefisen difusi masing-masing formula dapat dilihat pada tabel II.

Di tabel II terlihat bahwa dengan menaikkan konsentrasi DMSO, baik fluks maupun koefisien difusinya meningkat, sedangkan lag timenya menurun. Mengacu persamaan (7) bahwa lag time sebanding denga $\mathrm{h}^{2}$, dapat disimpulkan bahwa DMSO memiliki kemampuan memodifikasi membran atau berpengaruh terhadap ketebalan membran, terutama sel-sel mati stratum corneum yang menjadi barrier utama, dan ini yang menjadi dasar mengapa fluks dan koefisien difusinya meningkat.

Dari uji statistik menunjukkan bahwa fluks pada konsentrasi DMSO rendah $(0 \% ; 3 \% ; 5 \%)$ tidak menunjukkan perbedaan bermakna, tetapi pada konsentrasi DMSO yang lebih tinggi dengan konsentrasi $7 \%$ DMSO, semua formula menunjukkan perbedaan bermakna dengan formula 4 .

\section{KESIMPULAN}

Dari hasil percobaan dapat diambil kesimpulan bahwa konsentrasi DMSO dalam sediaan gel sangat mempengaruhi permeabilitas membran terhadap teofilin. Makin tinggi konsentrasi DMSO makin besar pula penetrasi teofilin pada membran. Penambahan $7 \%$ DMSO dapat meningkatkan fluks dan kofisien difusinya berturut-turut 10,3 kali dan 5,2 kali.

\section{DAFTAR PUSTAKA}

Anonim, 2013a, Find a Vitamin or Suplment

DMSO
(Dimetilsulfoxide), WebMD, diakses 26/02/2013, http://www.webmd.com.

Anonim, 2013b, Active Ingredient: dimethyl Sulfoxide - Brads, Medical Use, Clincal Data, Ingredient Info, DrugLib.com diaksen 26/02/2013 13:10, http://www.druglib.com.

Baumann, 2002, Cosmetic Dermatology Principles and Practice, 119, Me McGraw-Hill Companiec, New York.

Capriotti, and Capriotti, 2012, Dimethyl Sulfoxide, J. Clin.Aestet. Derm., 5 : 24-26.

Djajadisastra, Iskandarsyah, Novitasari, 2008, Pengaruh Bentuk AHA (Asam Laktat) terhadap Penetrasi Kafein sebagai Antiselulit dalam Sediaan Krim, Gel, dan Salep secara In Vitro, Prosiding Kongres Ilmiah ISFI XVI, 1 - 9

Djajadisastra, Sutriyo, Anggraeni, 2008, Pengaruh Bentuk Sediaan Krim, Gel, dan Salep terhadap Penetras In Vitro Aminofilin sebaga Antiselulit menggunakan Sel Difusi Franz, Prosiding Kongres Ilmiah ISFI XVI, 1 - 9

Donnelly, Singh, Morrow, Woolfson, 2012, Microneedle-mediated Transdermal and Intradermal Drug Delivery, $1^{\text {st }}$ Ed., 1-5, Wiley \& Sons, Ltd., USA

Higuchi, Fox, Knutson, Anderson, Flynn, 1985, The Dermal Barrier to Local and Systemic Drug Delivery in: Borchardt, R.T., Repta, A.J., and Stella, V.J., (Ed.), 
Directed Drug Delivery, 97 - 117, Humana, New Jersey

Jacob, and Herschler, 1983, Pharmacology of DMSO, DMSO Beckground Literature, diakses pada 26/02/2013, 12:45, htt://www.dmso.org/ articles/information/ herschler.htm.

Kravitz, and Achenbach, 2006, Cellulite: A Review of Its Anatomy, Physiology and Treatment, Untitled Document, http://dev.1simpleviewinc.com diakses tanggal 1 Maret 2013.

Kumar, Jain, Prajapati, 2011, Chemical Penetraton Enhancer DMSO on In Vitro Skin Permeation of Acyclovir Transdermal Microencalsulation Formulation, Int. J. Drug Deliv., 3 : 83 - 94.
Martin, Bustamante, Chun, 1993, Physical Pharmacy: Physical Ckemical Principles in the Pharmaceutical Sciences, $4^{\text {th }}$. Ed., 325 - 332, Lea \& Febiger, Phyladelphia.

Shembale, Borole,Lohiya, R.T., 2010, Useful Permeation Enhancers for Transdermal Drug Delivery: A Revew, Int. J. Pharm. Research \& Developments, 5 July 2012, www.jprd.com.

Trommer, and Neubert, 2006, Overcoming the Stratum Corneum: The Modulatatiom of Skin Penetrarion, Skin Pharmacology and Phisiology, 19: $106-121$. 
